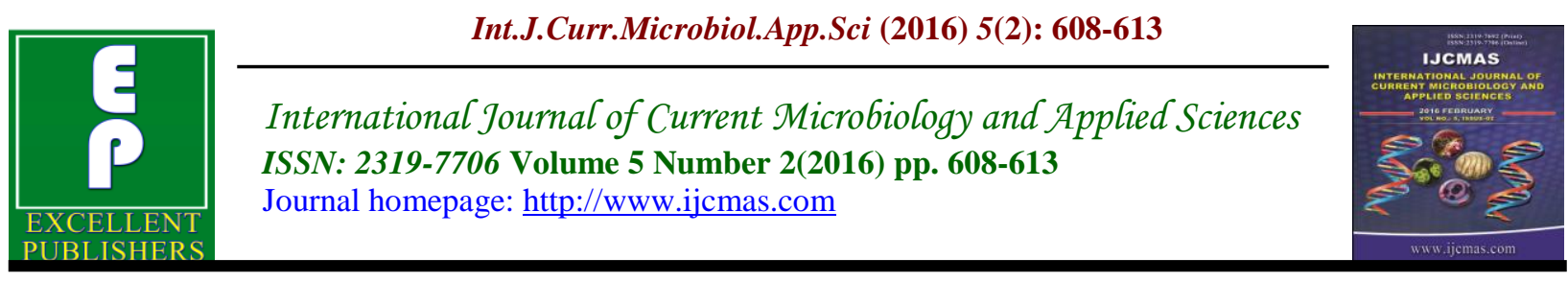

Original Research Article

doi: http://dx.doi.org/10.20546/ijcmas.2016.502.068

\title{
Effect of pH on Physicochemical Parameters of Wine Produced from Banana
}

\author{
Pradip D. Satav and Archana S. Pethe* \\ Department of Microbiology, Shri Shivaji College of Arts, Commerce and Science, \\ Akola, Maharashtra, India-444 001 \\ *Corresponding author
}

\begin{abstract}
A B S T R A C T
Keywords

Banana wine, soluble solid profile, $\mathrm{pH}$ profile, and physicochemical parameters of wine.

Article Info

Accepted:

26 January 2016

Available Online:

10, February 2016

Wine is a fermentation product of mainly grape fruit juice or other fruit juices. Banana fruit juice can also be used for production of wine. Several factors affect alcoholic fermentation of must. Fermentation $\mathrm{pH}$ may also affect the quality of the wine produced from a given banana variety. The aim of the present study was to study the effect of $\mathrm{pH}$ on different physicochemical parameters of wine made from banana variety (grand naine). Banana must was prepared from banana fruit by treating juice with pectinase enzyme, diluting with water, ameliorating to $20{ }^{\circ}$ Brix using sucrose and adding potassium metabisulfite. Then the $\mathrm{pH}$ of the must was adjusted as required. It was then subjected to pasteurization. The must was inoculated with yeast inoculum at $2 \%$ concentration. Soluble solid and $\mathrm{pH}$ profile of the wine was monitored daily. After fermentation physicochemical parameters of the wine were analysed. It was found that the must fermented at lower $\mathrm{pH}$ gives highest percentage of alcohol.
\end{abstract}

\section{Introduction}

Wine is a fermentation product of mainly grape fruit juice or other fruit juices. $\mathrm{pH}$ plays an important role in wine fermentations. During fermentation of fruit juice into wine, yeasts utilise sugars of juice as substrates for their growth and convert them in to ethanol, carbon dioxide, and other metabolic end products. These constituents contribute to the chemical composition and sensory quality of the wine. Several factors affect alcoholic fermentation, such as addition of sulphur dioxide, temperature of fermentation, $\mathrm{pH}$ of the must, composition of fruit juice, inoculation with specific yeasts, and interactions of microorganisms (Torija, et al., 2002, Jacobson, 2006).

The preferred wine $\mathrm{pH}$ is around 3.6 and the better $\mathrm{pH}$ for yeast and lactic acid bacteria is around 4.5. However spoilage bacteria can also grow well at $\mathrm{pH}$ 4.5. But, spoilage bacteria do not grow well below $\mathrm{pH}$ 3.6.Wine yeasts and some lactic acid bacteria can still metabolize in a $\mathrm{pH}$ range of 3.3-3.6. The low $\mathrm{pH}$ can prolong the fermentation process due to slow growth of microorganisms involved (Jacobson, 2006). 
Fruit wine including grape wine is generally produced by alcoholic fermentation of respective fruit by different strains of yeast, Saccharomyces cerevisiae. Fruits such as pomegranates, mangoes, papayas, bananas, pineapples, guavas, kiwis, dates, and passion fruits are being utilized for production of wine (Reddy et al, 2012). In recent years, literatures on production and characterization of wine from banana fruit are also increasing (Akubor, et al. 2003, Isitua, et al. 2011, Byaruagaba-Bazirake, et al. 2013, Alvarenga, 2013, Cheirsilp and Umsakul, 2008). However, there is limited information available about the effect of $\mathrm{pH}$ on fermentation profile and various physicochemical parameters of banana wine.

Fermentation $\mathrm{pH}$ may affect the quality of the wine produced from a given banana variety. Thus it is necessary to investigate the effect of $\mathrm{pH}$ on fermentation of banana must. In view of this, here we have made an effort to study the effect of $\mathrm{pH}$ on different physicochemical parameters of wine made from banana variety (grand naine) available in local area of Nanded district of Maharashtra, India.

\section{Preparation of Banana Juice}

Bananas were procured from local market of Nanded, Maharashtra. Healthy and fully ripe banana fruits with black stem were chose for the study. For preparation of juice, fruits were washed with tap water, disinfected with $70 \%$ ethanol and peeled manually by hands. Pulp was weighed and cut in to thin slices. Paste of banana pulp was made and mix with boiled hot water in 1:3 proportion (pulp:water) in grinder-mixer.

The diluted pulp thus obtained was then treated with pectinase enzyme at a total concentration of $0.05 \%(\mathrm{w} / \mathrm{v})$ of total juice volume for half an hour. Pectinase treated juice was kept in refrigerator (at $4^{\circ} \mathrm{C}$ ) for about18 hrs for clarification. After clarification, the juice was filtered through double folded muslin cloth and again diluted by adding one volume of water in three volume of juice (water:juice, 1:3). The juice was ameliorated to $20{ }^{\circ} \mathrm{Brix}$ using sucrose and $5 \mathrm{mg} / \mathrm{L}$ of potassium metabisulfite was added to it. It is then distributed in to $350 \mathrm{ml}$ aliquots in $500 \mathrm{ml}$ flasks for $\mathrm{pH}$ adjustments. Must with following $\mathrm{pH}$ ranges were prepared to study the effect of $\mathrm{pH}$ on fermentation parameters: 3.0, 3.5, 4.0 and 4.5 in duplicates. The $\mathrm{pH}$ was adjusted with citric acid and calcium carbonate. The flasks containing juice were plugged with cotton and pasteurised in autoclave at $85-90^{\circ} \mathrm{C}$ for 25 min. A control (pH 3.0) without pasteurization was also prepared. Must was then kept in refrigerator (at $4^{\circ} \mathrm{C}$ ) until required.

\section{Preparation of Inoculum/ Starter Culture}

Inoculum of the Baker's yeast ( $S$. cerevisiae) was prepared as follows: seven gram Baker's yeast was inoculated into 350 $\mathrm{ml}$ of banana must and grown at room temperature $\left(27-30{ }^{\circ} \mathrm{C}\right)$ for 68 hours. The cell number was counted by using haemocytometer. A cell density of approximately $3.2 \times 10^{9}$ cells $/ \mathrm{mL}$ was reached.

\section{Fermentation}

Must in each $500 \mathrm{ml}$ flask was inoculated with $7 \mathrm{ml}(2 \%, \mathrm{v} / \mathrm{v})$ of $68 \mathrm{~h}$ old starter culture of $S$. cerevisiae. Fermentation was carried out at room temperature $\left(25-28^{\circ} \mathrm{C}\right)$ for 14 days. To monitor the progress of fermentation process and to observe the effect of $\mathrm{pH}$ on fermentation profile of must, soluble solid and $\mathrm{pH}$ of each fermenting must were measured on alternate days after $24 \mathrm{~h}$ of inoculation. Fermentation was 
stopped when there were no evolution of gas bubbles by keeping the flasks in refrigerator at temperature of $3-5^{\circ} \mathrm{C}$. Two replicates were maintained for performing the experiment.

\section{Analysis}

During the fermentation, the fall in TSS $\left({ }^{\circ} \mathrm{B}\right)$, and the $\mathrm{pH}$, were monitored at the appropriate time intervals. The wines were analysed for different physico-chemical characteristics. The $\mathrm{pH}$ of the must and wine was measured with a digital $\mathrm{pH}$ meter (Systronics, India), pre-calibrated with buffers of $\mathrm{pH} 4.0$ and 7.0.

Titratable acidity was determined by titrating with $0.1 \mathrm{~N} \mathrm{NaOH}$ and alcohol \% by specific gravity method as described by AOAC. Total soluble solids (TSS) were determined using Abbey's refractometer (0 32 ) in terms of ${ }^{\circ}$ Brix (Jacobson, 2006). Free $\mathrm{SO}_{2}$ was determined by ripper titrametric method using iodine (Zoecklein, et al. 1995), and reducing sugars were determined calorimetrically using 3, 5-dinitrosalicylic acid (DNS) method as described by Nigam (2007).

\section{Results and Discussion}

We have investigated the effect of $\mathrm{pH}$ on the fermentation profile and physicochemical properties of banana must. The soluble solid and $\mathrm{pH}$ profile of banana must fermentation at different $\mathrm{pH}$ are presented in table 1 and 2 respectively.

\section{Soluble Solids ( ${ }^{0}$ Brix) Profile at Different pH}

Soluble solid ( ${ }^{\circ}$ Brix) represents the percent sugar and other dissolved solids in the solution. Decrease in soluble solids was observed during the fermentation of banana must. The rate of decrease was high in control without pasteurization, and in must with initial $\mathrm{pH} 4.0$ and 4.5. The decreased was lowest and moderate in must with $\mathrm{pH}$ 3.0 and 3.5 respectively. The must fermented at all $\mathrm{pH}$ had reached up to 6 ${ }^{\mathrm{o}}$ Brix except the control which had slightly lowered $5.9^{\circ}$ Brix.

The results suggested that $\mathrm{pH}$ did not significantly affected the ${ }^{\circ}$ Brix in fermented must and ultimately to the fermentation. However, $\mathrm{pH}$ could decrease the initial fermentation rate of banana must. Finally control without pasteurization could also had its microbial flora and might be responsible for utilization of dissolved solid i.e. sucrose.

\section{pH Profile of Must}

$\mathrm{pH}$ is important factor for the fermentation of fruit juice into a good quality wine. Low $\mathrm{pH}$ inhibits the growth of unwanted microflora and thus can improve the quality of final product. Complex pattern of $\mathrm{pH}$ variation was observed during fermentation of banana must at different $\mathrm{pH}$.

During initial days of fermentation, $\mathrm{pH}$ of the must was increased in all treatment except in must with initial $\mathrm{pH} 4.5$ which showed continuous fall and on last day a slight rise in its value. Banana must with $\mathrm{pH}$ 4.5 showed highest fall in $\mathrm{pH}$ on third day of fermentation. Significant fall was also observed in must with $\mathrm{pH}$ 4.0. The must showed alternate slight rise and fall in $\mathrm{pH}$ during fermentation. Pattern of rise and fall in $\mathrm{pH}$ was similar in both must with initial $\mathrm{pH} 3.0$ and 3.5. However, final $\mathrm{pH}$ of the must with initial $\mathrm{pH} 3.0$ was slightly increased from its initial value. Control without pasteurization also showed increased in $\mathrm{pH}$ from its initial 3.0 to final 3.3 . 
Table.1 Soluble Solid Profile of Must during Fermentation at Different $\mathrm{pH}$

\begin{tabular}{|l|l|l|l|l|l|}
\hline \multicolumn{6}{|l|}{ Soluble Solid ( ${ }^{\mathbf{0}}$ Brix) at different pH } \\
\hline Day & $\mathbf{p H ~ 3}$ & $\mathbf{p H ~ 3 . 5}$ & $\mathbf{p H ~ 4 . 0}$ & pH 4.5 & Control \\
\hline 0 & $20.0 \pm 0.0$ & $20.0 \pm 0.0$ & $20.00 \pm 0.0$ & $20.00 \pm 0.0$ & $20.0 \pm 0.0$ \\
\hline 1 & $19.80 \pm 0.2$ & $19.5 \pm 0.71$ & $19.00 \pm 0.0$ & $19.00 \pm 0.0$ & $19 \pm 0.0$ \\
\hline 3 & $18.00 \pm 0.01$ & $16.75 \pm 0.35$ & $16.50 \pm 0.0$ & $15.85 \pm 0.21$ & $16.5 \pm 0.3$ \\
\hline 5 & $13.5 \pm 0.0$ & $13.0 \pm 0.0$ & $13.25 \pm 0.0$ & $13.00 \pm 0.0$ & $13.0 \pm 0.0$ \\
\hline 7 & $10.75 \pm 0.30$ & $11.0 \pm 0.0$ & $10.00 \pm 0.0$ & $10.10 \pm 0.14$ & $10.0 \pm 0.0$ \\
\hline 9 & $8.8 \pm 0.0$ & $8.8 \pm 0.0$ & $8.80 \pm 0.0$ & $8.10 \pm 0.14$ & $8.0 \pm 0.0$ \\
\hline 11 & $7.0 \pm 0.0$ & $6.5 \pm 0.0$ & $7.65 \pm 0.91$ & $6.50 \pm 0.0$ & $6.5 \pm 0.5$ \\
\hline 13 & $6.0 \pm 0.0$ & $6.0 \pm 0.0$ & $6.00 \pm 0.00$ & $6.00 \pm 0.0$ & $5.9 \pm 0.2$ \\
\hline
\end{tabular}

(Mean \pm SD): Values are average of duplicates \pm Standard deviation

Table.2 Ph Profile of Banana must during Fermentation at Different $\mathrm{pH}$

\begin{tabular}{|l|l|l|l|l|l|}
\hline Day & $\mathbf{3}$ & $\mathbf{3 . 5}$ & $\mathbf{4 . 0}$ & $\mathbf{4 . 5}$ & Control \\
\hline 0 & $3.01 \pm 0.01$ & $3.50 \pm 0.0^{\mathrm{c}}$ & $4.00 \pm 0.00^{\mathrm{c}}$ & $4.50 \pm 0.0^{\mathrm{c}}$ & $3.00 \pm 0.02$ \\
\hline 1 & $3.22 \pm 0.02$ & $3.69 \pm 0.02$ & $4.06 \pm 0.01$ & $4.47 \pm 0.0$ & $3.13 \pm 0.01$ \\
\hline 3 & $2.84 \pm 0.02$ & $3.13 \pm 0.00$ & $3.21 \pm 0.01$ & $3.57 \pm 0.04$ & $3.18 \pm 0.03$ \\
\hline 5 & $3.01 \pm 0.03$ & $3.21 \pm 0.01$ & $3.31 \pm 0.01$ & $3.56 \pm 0.05$ & $3.29 \pm 0.03$ \\
\hline 7 & $3.00 \pm 0.02$ & $3.19 \pm 0.01$ & $3.25 \pm 0.00$ & $3.48 \pm 0.04$ & $3.26 \pm 0.05$ \\
\hline 9 & $2.98 \pm 0.01$ & $3.16 \pm 0.00$ & $3.26 \pm 0.02$ & $3.45 \pm 0.04$ & $3.22 \pm 0.02$ \\
\hline 11 & $2.99 \pm 0.02$ & $3.15 \pm 0.01$ & $3.21 \pm 0.00$ & $3.41 \pm 0.01$ & $3.18 \pm 0.03$ \\
\hline 13 & $3.09 \pm 0.02$ & $3.27 \pm 0.01$ & $3.33 \pm 0.01$ & $3.53 \pm 0.03$ & $3.30 \pm 0.01$ \\
\hline
\end{tabular}

(Mean \pm SD): Values are average of duplicates \pm Standard deviation

Table.3 Physicochemical Properties of Banana must after Fermentation at Different $\mathrm{pH}$

\begin{tabular}{|l|l|l|l|l|l|l|}
\hline $\mathbf{p H}$ & $\begin{array}{l}\text { Reducing } \\
\text { Sugar }(\mathbf{m g} / \mathbf{m l})\end{array}$ & $\begin{array}{l}\text { \% Tartaric } \\
\text { acid }\end{array}$ & Alcohol \% & $\begin{array}{l}\text { Free SO } \\
(\mathbf{m g} / \mathbf{L})\end{array}$ & $\begin{array}{l}\text { Specific } \\
\text { gravity }\end{array}$ & $\begin{array}{l}\text { Soluble } \\
\text { Solids } \\
\left({ }^{\mathbf{0} B r i x}\right)\end{array}$ \\
\hline Must & $68.50 \pm 0.07$ & $0.08 \pm 0.03$ & ND & $5.12 \pm 1.42$ & $1.082 \pm 0.003$ & $20.0 \pm 0.0$ \\
\hline 3 & $2.37 \pm 0.03$ & $0.68 \pm 0.01$ & $7.32 \pm 0.63$ & $8.45 \pm 0.0$ & $0.990 \pm 0.004$ & $6.0 \pm 0.5$ \\
\hline 3.5 & $2.42 \pm 0.02$ & $0.54 \pm 0.04$ & $6.67 \pm 0.43$ & $5.12 \pm 0.0$ & $0.990 \pm 0.001$ & $6.0 \pm 0.0$ \\
\hline 4 & $2.09 \pm 0.03$ & $0.42 \pm 0.0$ & $6.46 \pm 1.2$ & $6.78 \pm 1.27$ & $0.989 \pm 0.000$ & $6.0 \pm 0.0$ \\
\hline 4.5 & $1.96 \pm 0.01$ & $0.45 \pm 0.04$ & $6.71 \pm 0.3$ & $4.86 \pm 0.36$ & $0.990 \pm 0.001$ & $6.0 \pm 0.6$ \\
\hline Control & $1.44 \pm 0.05$ & $0.53 \pm 0.02$ & $6.55 \pm 0.52$ & $5.12 \pm 0.91$ & $0.989 \pm 0.000$ & $5.9 \pm 0.5$ \\
\hline
\end{tabular}

Must without pasteurization

ND: Not Detected 


\section{Physicochemical Properties of Banana must after Fermentation at Different pH}

Physicochemical properties are presented in table. Reducing sugar content of the must with initial $\mathrm{pH} 3.5$ and 4.5 were found to be highest $(2.42 \mathrm{mg} / \mathrm{ml})$ and lowest $(1.96$ $\mathrm{mg} / \mathrm{ml}$ ) respectively. Control without pasteurization also contained very low amount of reducing sugar $(1.44 \mathrm{mg} / \mathrm{ml})$. Thus with increased in $\mathrm{pH}$ the utilization of reducing sugar by wine microflora also increased, except at $\mathrm{pH}$ range 3.0 to 3.5 where almost similar amount of reducing sugar was remained. Titratable acidity (\% tartaric acid) of the must with initial $\mathrm{pH} 3.0$ and 4.0 were found to be respectively highest $(0.68 \%)$ and lowest $(0.42 \%)$ after fermentation. Original must had very low titratable acidity $(0.075 \%)$. Fermentation of must resulted in to increase in titratable acidity. With increased in $\mathrm{pH}$, titratable acidity of the fermented must was found to be decreased. Highest and lowest concentration of reducing sugars was observed in must fermented at $\mathrm{pH} 3.5$ and 4.5 respectively.

Alcohol percent of the must with initial $\mathrm{pH} 3$ was found to be highest (7.32\%). At other $\mathrm{pH}$ alcohol percent was found to be lower.

With decrease in $\mathrm{pH}$, alcohol percent does not increase linearly. However, low $\mathrm{pH}$ favours high alcohol production. This might be due to the inhibition of growth of other microbial flora at low $\mathrm{pH}$ and more alcohol production by yeast. Specific gravity of the must fermented at all $\mathrm{pH}$ almost had same value around 0.990. However, it is significantly lowered than the specific gravity of must. Concentration of $\mathrm{SO}_{2}$ was also found to be almost similar in all must fermented at different $\mathrm{pH}$. Soluble solid content was decrease in all fermented must at all $\mathrm{pH}$.
Various factors such $\mathrm{pH}$, temperature, concentration of sugars, etc can affect the physicochemical parameters of wine during its fermentation. $\mathrm{pH}$ is one of the important factor which affect the growth and metabolism of yeast. Generally acidic $\mathrm{pH}$ is favourable for wine microorganisms and the optimum $\mathrm{pH}$ for the growth of yeast and lactic acid bacteria is around $\mathrm{pH}$ 4.5. (Jacobson, 2006). Fall in pH and increase in titratable acidity was observed after fermentation of banana must. Similar observations were reported by other authors for banana wine (Onwuka and Awam, 2001, Akubor, et al, 2003). Metabolic activity of yeast and other microorganisms present in must probably be the responsible factor for the increase in titratable acidity and decrease in $\mathrm{pH}$ (Akubor, et al. 2003; Okoro, 2007; Alobo and Offonry, 2009; Panda et al. 2014; and Chowdhury and Ray, 2007). Banana must having $\mathrm{pH} 3.0$ showed slight increase in $\mathrm{pH}$ value.

At all $\mathrm{pH}$, decrease in soluble solid $\left({ }^{\circ} \mathrm{Brix}\right)$ was also observed. This decrease was due to utilization of sucrose by must microorganism. Similar results were found by Onwuka and Awam (2001) and Akubor, et al, (2003) for fermentation of banana must. However they reported very low soluble solid ( ${ }^{\mathrm{B}} \mathrm{Brix}$ ) as compared to our results.

The specific gravity of must was decreased after fermentation at all $\mathrm{pH}$. This decrease was attributed to decrease in soluble solid $\left({ }^{\circ} \mathrm{Brix}\right)$ and increase in alcohol \% during fermentation by yeast. Free $\mathrm{SO}_{2}$ in all fermented must remained almost constant. Optimum $\mathrm{pH}$ for production of alcohol during fermentation of banana must was found to be 3.0. In contrast to our results some authors have reported higher (Ranjitha, et al., 2015, Onwuka and Awam, 2001) and lower alcohol percentage at high 
$\mathrm{pH}$ (Akubor, et al., 2003) than we found. This might be due to the differences in experimental condition.

In conclusion, Study was carried out to determine the effect of $\mathrm{pH}$ on physicochemical parameters of banana must after fermentation. Must fermented at lower $\mathrm{pH}$ gives highest percentage of alcohol and titratable acidity. Further studies are needed to investigate the effect of other parameters on fermentation of banana must by using Saccharomyces cerevisiae.

\section{References}

Akubor, P.I., Obio, S.O., Nwadomere, K.A., and Obiomah, E. 2003. Production and quality evaluation of banana wine. Plant Food Human Nutr. 58(3):1-6

Alobo, A.P., and Offonry, S.U. 2009. Characteristics of coloured wine produced from Roselle (Hibiscus sabdariffa) calyx extract. J. Inst. Brew. 115(2):91-94.

Alvarenga, R.M., Carrara, A.G., Silva, C.M., and Oliveira, E.S. 2013. Potential application of saccharomyces cerevisiae strains for the fermentation of banana pulp. Afr $\mathbf{J}$ Biotechnol. 10(18):3608-3615.

AOAC. 1980. Official methods of analysis. Association of official analytical chemist, 13th Edn. Washington DC.

Byaruagaba-Bazirake, G.W., Rensburg, P.V., and Kyamuhangire, W. 2013. Characterisation of banana wine fermented with recombinant wine yeast strains. Am J Food Nutr. 3:105116.

Cheirsilp, B., and Umsakul, K. 2008. Processing of banana-based wine product using pectinase and $\alpha$ amylase. J Food Proc Eng. 31:78-90.

Chowdhury, P., and Ray, R.C. 2007. Fermentation of Jamun (Syzgium cumini L.) Fruits to form Red Wine. ASEAN Food J. 14(1):15-23.

Isitua, C.C., and Ibeh, I.N. 2010. Novel method of wine production from banana (Musa acuminata) and pineapple (Ananas comosus) wastes. Afr J Biotechnol. 9(44):75217524.

Jacobson, J.L. 2006. Introduction to wine laboratory practices and procedures. Springer Science \& Business Media, New York, pp 164-166, 269-271.

Nigam, A. 2007. Lab manual in biochemistry, immunology and biotechnology. Tata McGraw-Hill Publisher, New Delhi, pp 35-36.

Okoro, E.C. 2007. Production of red wine from roselle (Hibiscus sabdariffa) and pawpaw (Carica papaya) using palmwine yeast (Saccharomyces cerevisiae). Nigerian Food J. 25(2):158-164.

Onwuka, U., and Awam, F.N. 2001. The potential for baker's yeast (Saccharomyces cerevisiae) in the production of wine from banana, cooking banana and plantain. Food Serv Technol. 1(3-4):127-132.

Panda, S.K., Sahu, U.C., Behera, S.K., and Ray, R.C. 2014. Bio-processing of bael [Aegle marmelos L.] fruits into wine with antioxidants. Food Biosci. 5:34-41.

Ranjitha, K., Narayana, C.K., and Roy, T.K. 2015. Process standardization and quality evaluation of wine from Cavendish banana (Musa, genome AAA) cv. Robusta. Indian J Horticul. 72(1):153-155.

Reddy, L.V.A., Joshi, V.K., Reddy, O.V.S. 2012. Utilization of tropical fruits for wine production with special emphasis on mango (Mangifera indica L.) wine. In: Microorganisms in Sustainable Agriculture and Biotechnology. Springer Publisher, Netherland, pp 
679-710.

Torija, M.J., Rozes, N., Poblet, M., Guillamón, J.M., and Mas, A. 2003. Effects of fermentation temperature on the strain population of Saccharomyces cerevisiae. Intern. J. Food Microbiol. 80(1): 47-53.
Zoecklein, B.W., Fugelsang, K.C., Gump, B.H., and Nury, F.S. 1995. Wine analysis and production. Springer Science \& Business Media, New York, pp 493-496.

\section{How to cite this article:}

Pradip D. Satav and Archana S. Pethe. 2016. Effect of $\mathrm{pH}$ on Physicochemical Parameters of Wine Produced from Banana. Int.J.Curr.Microbiol.App.Sci.5(2): 608-614. doi: http://dx.doi.org/10.20546/ijcmas.2016.502.068 